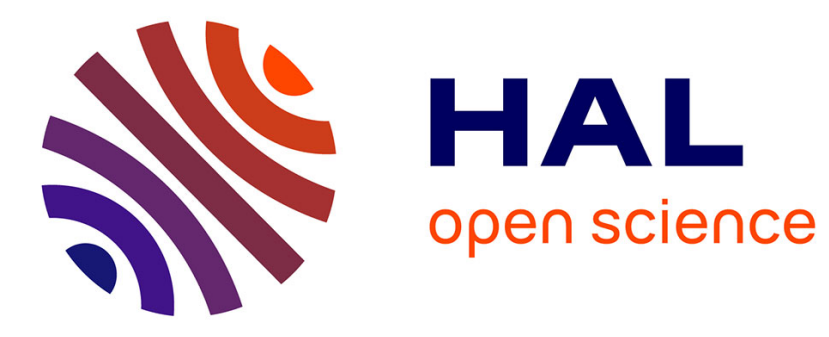

\title{
Self-sufficiency assessment: Defining the foodshed spatial signature of short beef supply chains
}

Michel Moulery, Esther Sanz Sanz, Marta M. Debolini, Claude Napoleone, Didier Josselin, Luc Mabire, José Luis Vicente-Vicente

\section{- To cite this version:}

Michel Moulery, Esther Sanz Sanz, Marta M. Debolini, Claude Napoleone, Didier Josselin, et al.. Self-sufficiency assessment: Defining the foodshed spatial signature of short beef supply chains. 2022 . hal-03524862

\section{HAL Id: hal-03524862 \\ https://hal.inrae.fr/hal-03524862}

Preprint submitted on 13 Jan 2022

HAL is a multi-disciplinary open access archive for the deposit and dissemination of scientific research documents, whether they are published or not. The documents may come from teaching and research institutions in France or abroad, or from public or private research centers.
L'archive ouverte pluridisciplinaire HAL, est destinée au dépôt et à la diffusion de documents scientifiques de niveau recherche, publiés ou non, émanant des établissements d'enseignement et de recherche français ou étrangers, des laboratoires publics ou privés. 


\title{
Self-sufficiency assessment: Defining the foodshed spatial signature of short beef supply chains
}

\author{
Mouléry $\mathrm{M}^{1}$, Sanz Sanz E ${ }^{1,3}$, Debolini $\mathrm{M}^{1}$, Napoléone $\mathrm{C}^{1}$, Josselin $\mathrm{D}^{2}$, L Mabire ${ }^{2}$, Vicente- \\ Vicente $\mathrm{JL}^{3}$ \\ ${ }^{1}$ French National Institute for Research on Agriculture, Food and Environment (INRAE), UR- Ecodéveloppement, 228 route de \\ l'aérodrome CS 40509, 84914 Avignon Cédex 9 (France) \\ ${ }^{2}$ UMR ESPACE 7300 (CNRS), Avignon university, 74 Rue Louis Pasteur, Campus Hannah Arendt, 84029 Avignon (France) \\ ${ }^{3}$ Leibniz Centre for Agricultural Landscape Research (ZALF), Eberswalder Str. 84, 15374, Müncheberg (Germany)
}

\begin{abstract}
Foodshed approaches allow the assessment of the theoretical food self-sufficiency capacity of a specific region based on biophysical conditions. Recent analyses show that the focus needs to be shifted from foodshed size portrayed as an isotropic circle to a commodity-group-specific spatial configuration of the foodshed that takes into account the socio-economic and biophysical conditions essential to the development of local food supply chains. We focus on a specific animal product (beef) and use an innovative modeling approach based on spatial analysis to detect the areas of the foodshed dedicated to beef feeding (forage, pasture, and grassland), considering the foodshed as a complex of complementary areas called an archipelago. We use available statistical data including a census to address the city-region of Avignon (France) covering a $100 \mathrm{~km}$ radius. Our results show that the factors driving the use of short supply chains for beef feeding areas are the foodshed archipelago's number of patches, the connectivity between them, and the rugosity of the boundaries. In addition, our beef self-sufficiency assessment results differ depending on geographical context. For instance, being located within the perimeters of a nature park seems to help orient beef production towards short supply chains. We discuss possible leverage for public action to reconnect beef production areas to consumption areas (the city) via short supply chains (e.g. green, home-grown school food programs) so as to increase local food security through increased local food self-sufficiency.
\end{abstract}

Keywords: foodshed archipelago; proximity food supply chains; spatial signature; city-region; food selfsufficiency; regional food security; agricultural diversification; food planning; regional food system; food policy

\section{Introduction}

The Covid-19 health and economic crisis has exposed the weakness of food systems and shown the vulnerability of food supply chains to social, economic or natural hazards. This is especially true in urban areas, which largely rely on food imported from the global market [1]. Actually, the population of urban areas has exceeded that of rural areas since 2008, and this proportion is expected to increase to $66 \%$ by 2050 [2]. Each disruption in global food supply chains has become a social and political issue,, prompting a focus on relocalization of food supply and regionalization of food systems [3]. However, peri-urban agricultural areas are not homogenous, and not every farming system is able to respond to local food demand in terms of foodstuff diversity or quantities [4-6]. In addition, geo-physical spatial heterogeneity means that soils differ in their suitability for agriculture. Yet there are few tools available to inform public policies aimed at supporting the regionalization of food systems, particularly to identify the farmland areas where farmers can best respond to incentives.

Current research is highlighting foodshed approaches as a way of identifying the farmland areas functionally linked to cities that could be involved in new short food supply chains [7]. In this paper, we first briefly sketch the state of the art concerning the notion of foodshed. Then we describe a study 
case in southern France to which we applied a foodshed approach to analyze beef supply chains, using a new methodology. Our method is based on spatial metrics grounded in theories of landscape ecology, and on proximity relations in regional development processes. Finally, we present our results and discuss their implications for further research on the regionalization of food systems.

\subsection{Foodshed approaches}

The notion of "foodshed" was first used by W. Hedden in 1929 in the book How Great Cities are $\mathrm{Fed}$, to describe "the geographic area from which food arrives in a community, including the rural and urban farmlands, processing and distribution facilities, transportation systems, wholesalers and retailers that make up a region's food system" [8]. In October 1921, a planned nationwide railway strike was threatening New York with the danger of interrupted food supplies to a large city dependent on distant food sources and losing nearby farmland to the suburbs. This prompted Walter P. Hedden, head of the Port Authority of New York's Bureau of Commerce, to write a comprehensive assessment of the city's food supply. Hedden mapped food flows from different locations in the United States, looked at criteria such as seasonality or the origin of food, and studied the logistical infrastructure (rail lines, cooling and storage facilities, distribution centers, and food shops). In 1996, Kloppenburg et al. proposed the term 'foodshed analysis' to inform policy decisions on local food sufficiency or insufficiency [9]. Foodshed analysis can be seen as a comprehensive approach to improving the sustainability of regional food systems [10]. For instance, by determining the potential and risks for agricultural production capacity from the analysis of bioclimatic variables (climate, soil type resources) [11], by assessing the environmental impact and vulnerability of local food systems depending on food origin [12] or by examining whether shortening food supply chains can help maintain agriculture close to urban areas [13].

In this paper, we define the term "foodshed" as the geographical area in which food is grown to satisfy the food needs of a population from its own domestic production. The foodshed approaches varies depending on the scale of the analysis and the objective: to assess whether total local food demand can be met by local production capacity $[\mathbf{1 4 , 1 5 ]}$, or to assess the production capacity required to meet local food demand [16]. The foodshed approach has also been used to estimate the size of foodshed required to meet a given rate of food self-sufficiency, taking into account different food system scenarios in terms of food groups, food production systems (conventional versus organic), diets, and levels of food loss and waste ( e.g., the Metropolitan Foodshed and Self-sufficiency Scenario: MFSS; Zasada et al., 2019). Thus, in addition to food production capacity based on biophysical conditions, our recent work considered socioeconomic features driving the flows and distribution networks of locallygrown food. Our findings showed that analysis needs to be shifted from size assessment of the foodshed represented as an isotropic circle around the city, to commodity-group-specific spatial configuration of the foodshed [7]. The aim of the present study is to explore foodshed assessment as a complex of complementary entities, i.e., the "foodshed archipelago". To this end, we develop a framework grounded in landscape ecology, namely the Island Biogeography Theory, the Continent-island Model Theory, and the Connectivity Theory. In other words, we assume that the foodshed is not an isotopic circle but a set of connected specific food production areas (patches) that are inter-connected by production and marketing conditions (i.e., the urban food supply chain) to form an archipelago, and which distribute specific foodstuffs by means of short supply chains (i.e., a foodshed archipelago). In this study, we focus on the landscape structure of the entities composing the foodshed archipelago without considering a link to behavioral attributes of organisms [18]. To test our hypothesis, we analyze the beef foodshed of a study case located in Avignon (France). Cattle production was chosen because it is extremely challenging around Mediterranean cities like Avignon, due to the prevailing pedo-climatic conditions (water and grassland scarcity). Our objective is to determine whether this beef 
foodshed archipelago has a specific spatial signature, different from that of beef production areas serving long supply chains. By "spatial signature", we mean particular spatial structures whose arrangement is identifiable in space resulting in a set of common characteristics, such as crop plot shape, location of farmstead, border relationship between farming and urban zones, etc. $[5,6,19]$.

\subsection{Foodshed analysis based on landscape ecology and proximity theories}

Our analytical framework is grounded in theories of landscape ecology and based on the proximity relations pertaining to regional development processes. The first landscape theory behind our work is island biogeography, often defined as the study of the geographical distributions of organisms [20]. The Island Biogeography Theory (IBT) proposed by MacArthur and Wilson in 1967 [21] seeks to identify and measure the effects of island colonization by species and to understand their future evolution or species disparity. They deduce that the biodiversity of an island is proportional to its surface area (the larger the island, the more species there will be); however, it is inverse proportional to distance (more distant islands have less biodiversity) [22]. The IBT has been used to analyze, for instance, the species richness of insectivorous birds on forested islands induced by a large hydroelectric dam [23], and to understand the problem of biodiversity conservation in the face of increasing extinction risk in small isolated areas [24]. Our second theoretical basis is the Continent-Island Model Theory, which maintains that a local population, called "source", provides individuals to other local populations, called "sink" [25]. Within this interplay of colonizations and extinctions, any habitat can be both "source" and "sink" [26]. Following this approach, we considered a "sink" located in Avignon, which can be portrayed as a large patch requiring resources (beef supply). The "sources" are the other patches, an assembly of pastoral and grassland areas within a radius of $100 \mathrm{~km}$ around Avignon. The assembled sources configure the foodshed archipelago. Thirdly, our analysis of the way they are assembled is based on the Connectivity Theory. Here, pastoral areas and grasslands are considered as spatial objects or "patches" that are heterogeneous in terms of size and shape. Their actual geographical distribution (i.e. density) is not homogeneous. In general, neighboring patches or adjacent plots are more likely to be connected to each other than an isolated plot. Landscape connectivity is thus defined as the degree to which the landscape facilitates or impedes movement between resource patches [27]. This definition highlights the impact that the types, quantity, and arrangement of habitats or land uses have on movement and ultimately population dynamics and community structure. Landscape connectivity therefore describes both the physical structure of the landscape and the response of an organism to that structure [28].

From the perspective of the economic geography theory of proximity relations, short supply chains can only be structured if the three dimensions of proximity are respected, namely geographical proximity (i.e. distance), organized proximity (i.e., the different ways of being close to other stakeholders, referring to the arranged nature of human activities), and institutional proximity (i.e., the political dimension or adherence to a space that is defined by common rules of action, representations, thought patterns) [29,30]. Our aim here is to define the spatial signature of the beef production areas serving short supply chains in terms of the three dimensions of proximity. We analyze an empirical case study in the Avignon foodshed, using a 4-step methodology. Geographical proximity is measured by distance to the slaughterhouses (cf. 2.4.1). Organized proximity is considered through geographical proximity and under an analytical framework inspired by landscape ecology, measuring the rugosity of the contours of beef production areas (cf. 2.4.2) and dominance (cf. 2.4.3) to account for the territorial embeddedness of these farms [31-33]. Finally, institutional proximity is considered according to whether or not the beef production areas lie within the perimeter of a regional or national nature park (cf. 2.4.4). 


\section{Materials and Methods}

\subsection{Study area}

Following previous work [7], we defined a radius of $100 \mathrm{~km}$ around Avignon, a medium-sized city located in south-eastern France. The selected area incorporates three different administrative regions and ten different provinces (the French départements): Bouches-duRhône, Vaucluse, Var, Hautes Alpes in the Provence-Alpes-Côte d'Azur region, Gard, Hérault, Lozère in the Occitanie region and Ardèche and Drome in the Auvergne-Rhone-Alpes region (Figure 1). It numbers 1358 communes, including 738 municipalities containing at least one beef farm selling part of its production in short supply chains. The Avignon periurban area is a fertile plain that has historically benefited from irrigation and transport infrastructures fostering market gardening, fruit growing, and viticulture. More recently, part of Avignon's agriculture has also turned to large-scale cash crops (cereal and lavender). There is a predominance of municipalities specialized in wine-growing in our study area, seeming to form a structured arc along the Rhône, in the Vaucluse, Gard, and Bouches-du-Rhône. Actually, viticulture is a strongly supported and structured sector [34]. Only by moving away from the Avignon conurbation and the arc formed by the wine-growing communes can substantial areas potentially suitable for the grassland and pastoralism linked to beef production be found. They are overwhelmingly concentrated in the north of our study area on the Plateau de Coiron (Ardèche), Lozère and the Monts de Vaucluse (Vaucluse and Alpes de Haute-Provence), but there is also extensive cattle breeding in the municipalities of Camargue and Crau located in the south of the study area. However, these communes specialize in rearing herds of Camargue races for recreational purposes (ex. bullfighting festivals) and not for food production, so their analysis has been contextualized.

\subsection{Materials used to identify beef production areas}

To spatially identify grasslands and pastoral areas, we used the 2018 plot identification system (LPIS) graphically represented in the French Registre Parcellaire Graphique (RPG; https://www.data.gouv.fr), which geolocates and informs on areas under different EU Common Agricultural Policy (CAP) aid schemes. This is a very accurate vectoral data source that relies on farmers' own hand-drawn outlines of their cultivated plots submitted when applying for CAP subsidies. We selected three categories of land used for beef feeding: wood-pastures, permanent grasslands and temporary grasslands (Table 1).

Table 1. Selected RPG categories of land use for beef feeding 


\begin{tabular}{lll}
\hline Category & Description & Code \\
\hline & Wood-pasture & BOP
\end{tabular}

Pastoral area - predominantly grass and fodder resources. Woody

Estives, moors resources present

SPH

Pastoral area - predominantly woody fodder resources

$\begin{array}{ll}\text { Permanent } & \text { grassland } \\ \text { predominantly } & \text { grass (fodder }\end{array}$
resources; woody resources absent

Permanent grassland or little present)

$\mathrm{PPH}$ grassland in long rotation (6 years or more)

PRL

Other temporary grassland 5 years PTR

Temporary grassland old or less

SPL

\section{Temporary grassland}

After aggregating these land-use categories, we considered patches as potentially serving short supply chains if they fall within the administrative boundary of municipalities with at least one beef farm partly selling through short supply chains, according to the 2010 general agricultural census (source https://www.agreste.agriculture.gouv.fr) at municipal level. We analyzed patch connection using the "dilation/erosion" method described below. Other sources of complementary data used were the location of slaughterhouses (source: Maison Régional de l'Elevage PACA, Chambre Agriculture Drôme, Chambre Agriculture Ardèche and Chambre Agriculture Gard) and the environmental protection perimeters of national and regional nature parks.

\subsection{The dilation/erosion methodology}

The dilation/erosion methodology is grounded in landscape ecology and widely used for research in different disciplines, including medicine and urban planning, to analyze the morphology of geometric structures. Applications include the creation of a dilated envelope around built-up areas [35,36], and analysis of the distances between two natural areas to highlight the most direct paths to connect them in a "green and blue grid" [37]. It is based on algebra, topology, and probability concepts.

Here, we connected the vectorized plots of the three selected RPG categories of land use for beef feeding (estives moors, permanent grassland, temporary grassland) at a minimum distance of 20 meters, taken as the average rough width of roads and paths. The plots were grouped using 
the dilation method. Then erosion was generated to refine the contours of the aggregated plots and create patches (Figure 1). Isolated plots more than 20 meters away from their nearest neighbor were considered as patches in landscape ecology terms. Technically, a procedure was created using the spatial functions of the UrbanSimul project programmed in postgis [38].

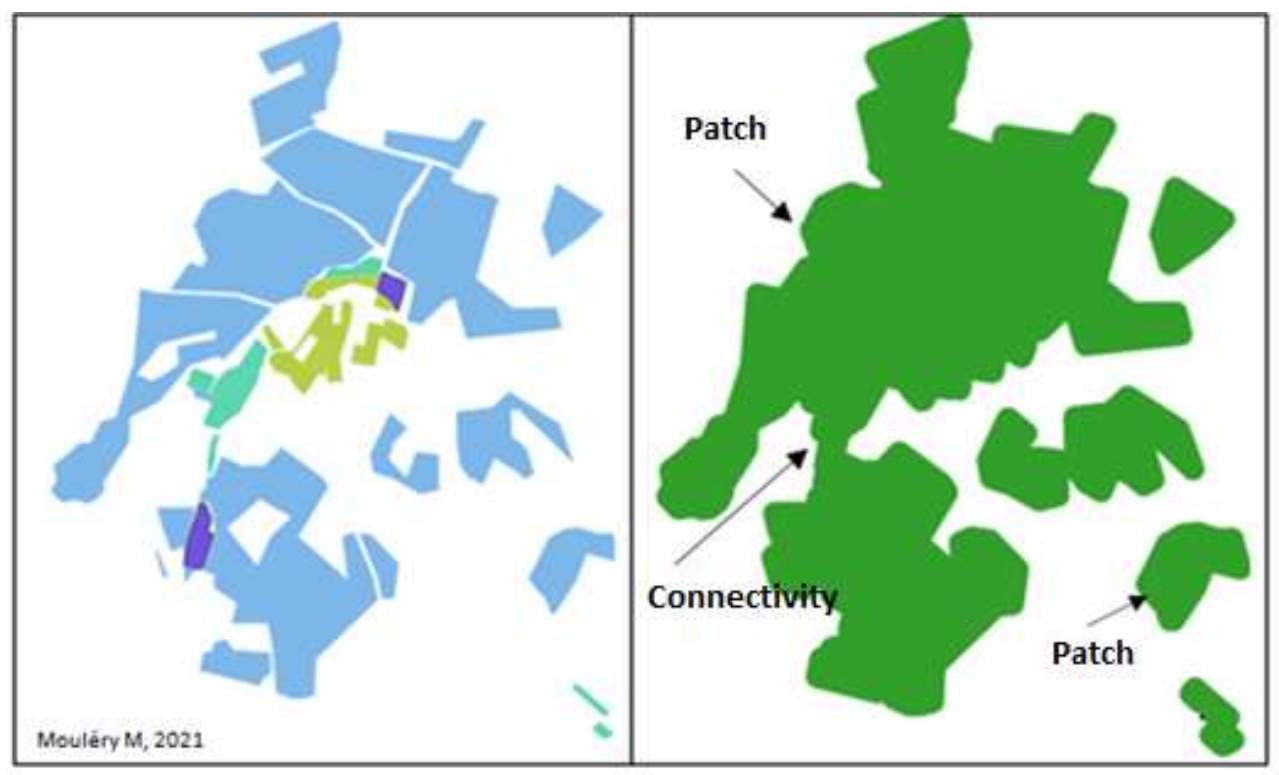

Figure 1. Before Dilation/Erosion

Dilation /Erosion (creation of the archipelago)

We mapped two sets of data: potential beef feeding areas oriented and not oriented towards short supply chains (Figure 2). The geographical entities of substantial size that are considered patches oriented towards beef short supply chains are shown in green. The largest such patches are located in Ardèche, Drome, Alpes de Haute Provence, areas producing beef breeds such as "Limousine" and "Charolais". Another large patch in the Bouches du Rhône hosts Camargue herds raised for recreational purposes. 


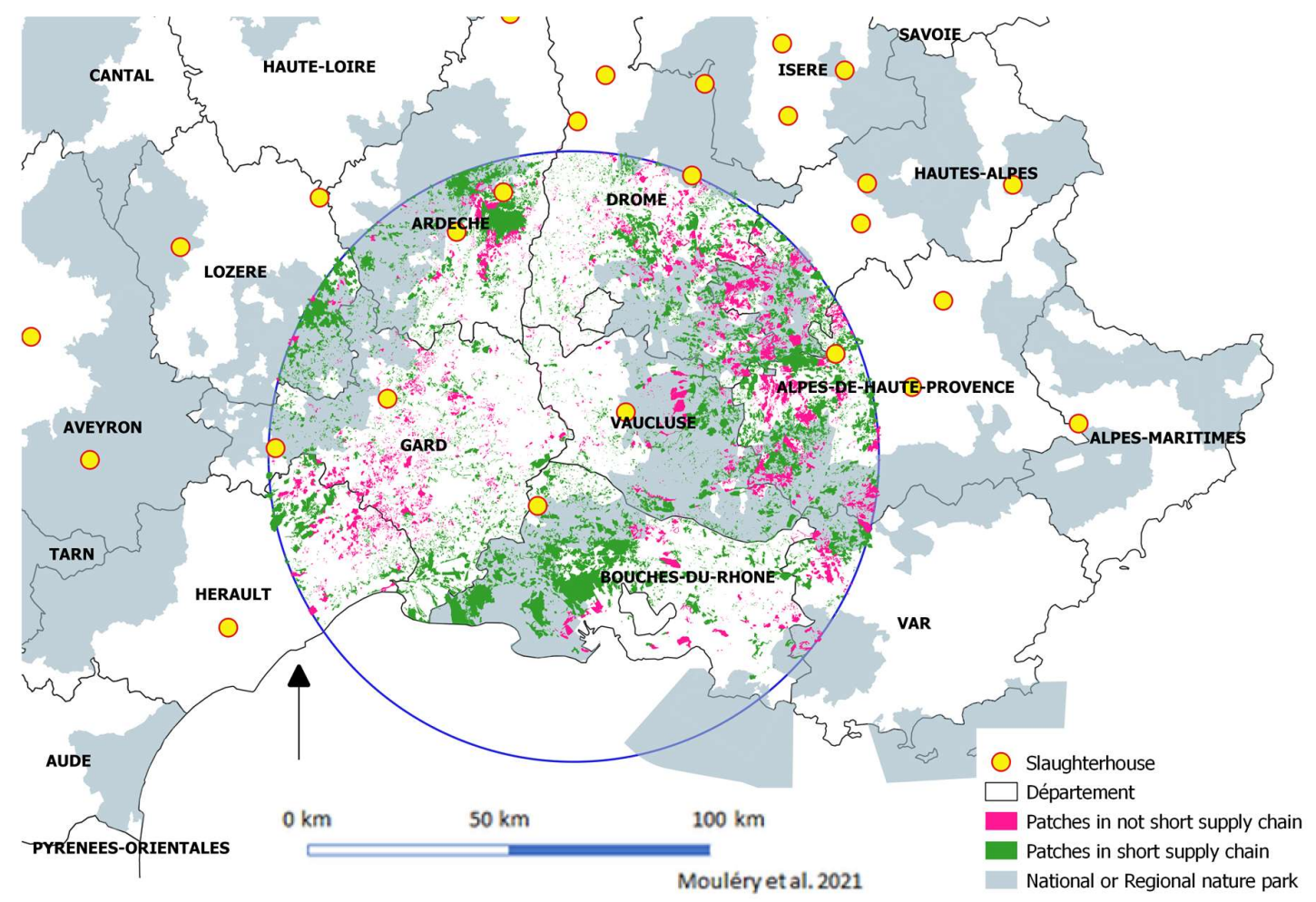

Figure 2. Location of the beef feeding patches within a $100 \mathrm{~km}$ radius around the city of Avignon.

\subsection{Method used to spatially characterize beef feeding patches in the archipelago oriented and not oriented towards short supply chains}

This section examines whether the spatial signature of areas oriented and not oriented towards short supply chains can be distinguished from each other according to spatial analysis indicators. The goal is to identify areas (patches) more likely to respond to institutional incentives to increase food security by enhancing/promoting short supply chains. We relied on simple tools used in spatial analysis to assess: 1) the effects of distance from nearest slaughterhouse; 2) rugosity, defined as the complexity of the contours of patches; 3 ) dominance, according to density, number of patches oriented towards short circuits, and total surface area, and 4) the effects of being situated within the perimeters of a regional or a national nature park. The methods used to analyze/assess/calculate the four indicators are described below.

\subsubsection{Distance from nearest slaughterhouse}

The slaughterhouses in the study area are geolocated by a yellow dot (Figure 2). A geographic information system was used to calculate the minimum distance from each centroid of the beef feeding areas (patches) to the nearest slaughterhouse, discriminating between areas oriented and not oriented towards short supply chains. The underlying hypothesis is that production areas used by farmers selling beef in short supply chains are nearer to a slaughterhouse than those used by farmers not selling beef in short supply chains. Actually, local slaughterhouses 
are small-scale structures providing less than 2,000 tonnes of meat per year by slaughtering on behalf of farmers who then sell their meat on markets, to artisan butchers or in shops specializing in local and organic products. These farmers and butchers rely on short supply chains to reduce intermediaries and add value to their products [39].

\subsubsection{Rugosity}

The rugosity indicator is based on the complexity of the contours of the patches. This indicator was constructed on the basis of ecology research on the rugosity of coral reefs showing that the greater the structural complexity of ecological habitats, the greater the diversity of species [40]. This concept of rugosity was taken up by Catherine Brinkley [41] for the urban system, under the hypothesis that high complexity of the contours of the urban-agricultural fringe increases the functional connections between urban and agricultural land uses. She concluded that increased rugosity is associated with large populations and significant historic peri-urban farm holdings involved in direct marketing. In this paper, we widen this hypothesis beyond direct marketing, seeking to determine whether the rugosity of the farming areas fosters the orientation of beef production towards short supply chains. In other words, whether former cattle production areas oriented towards long supply chains generate more homogeneous limits than newcomers in short supply chains that are more randomly located. Thus, we measured the rugosity of beef feeding areas (patches) both oriented and not oriented towards short supply chains. We used the Gravelius index $(\mathrm{K})$, that is the ratio of the perimeter of the patch to the circumference of a circle of the same area surrounding it [42]. We applied the formula: $K=$ perimeter $/ 2^{*} \sqrt{ }(\pi /$ area $)$. The farther $K$ is from 1 , the more complex the contours are. The results are presented in section 3 .

\subsubsection{Dominance}

After applying the dilation/erosion method, we assessed dominance according to three indicators: 1) the density of the selected RPG categories of land use in the archipelago, discriminating between areas oriented and those not oriented towards short circuits; 2) the number of plots aggregated in the patch (as a proxy of productive crop-plot fragmentation) within the archipelago and 3) the total area of patches discriminating between those oriented towards short or long supply chains. It is assumed that the larger the patches, the more likely they are to generate a foodshed capable of feeding the city, compared to small, scattered pastoral plots. We define density as the relationship between the surface areas registered in the RGA census (i.e. the selected RPG categories of land for beef feeding, see Table 1) and the surface areas of the patches they lie in, as determined by dilation/erosion, discriminating between those oriented and those not oriented towards short supply chains. The density indicators are calculated over a range of thresholds defined between 50 and 1000 hectares (total average of RPG areas related to the vectorized contours of the patches).

\subsubsection{Location within the perimeters of a regional or a national nature park}

The national parks were created in 1973 to ensure the protection of natural areas, both terrestrial and maritime. Pastoral practices are allowed on areas of great biological richness and landscape interest: high mountain pastures and estives (summer pastures), inter-seasonal rangelands, mown natural meadows, etc. In summer, the mountain pastures and estives also host numerous transhumant herds, sometimes coming from distant departments of southern France (http://www.parcsnationaux.fr/fr/des-connaissances/agriculture-et-pastoralisme). The regional nature parks were created under French regional planning policy in 1967 as an original way of promoting sustainable development strategies based on regional agricultural and agri-food resources [43]. Their participatory approaches contribute to the economic, environmental, and social balance of the territories under a contractual charter signed by the stakeholders. Regional parks generally promote the quality of the landscape and protect small farms, who can add value to their food products through the regional nature park quality label. Therefore, the 
hypothesis underlying our study is that beef feeding areas located within the perimeters of a regional or a national nature park are more likely to be oriented towards short supply chains.

\section{Results}

3.1 Higher contour rugosity is found for entities oriented towards short supply chains than for those oriented towards long supply chains

We investigated whether the rugosity of the contours defined by the Gravelius indicator $\mathrm{K}$ is a consequential variable distinguishing between short and long supply chains. When this indicator is calculated in the $100 \mathrm{~km}$-radius foodshed, the average $\mathrm{K}$ value of entities (isolated patches and archipelago) in short supply chains (SSC) is slightly higher than in long supply chains (LSC) (Table 2). We conclude that contour rugosity is informative on whether beef feeding areas are functionally connected to nearby beef consumption areas, thereby confirming the hypothesis defined in 2.4.2.

Table 2. Average rugosity of entities constituting beef feeding areas

\begin{tabular}{ccc}
\hline Surface (ha) & K (SSC) & K (LSC) \\
\hline$<50$ & 1.22 & 1.21 \\
\hline$>50$ & 2.19 & 2.10 \\
\hline$>100$ & 2.45 & 2.32 \\
\hline$>300$ & 3.02 & 2.82 \\
\hline$>500$ & 3.36 & 3.01 \\
\hline$>700$ & 3.59 & 3.29 \\
\hline$>1000$ & 3.36 & 3.01 \\
\hline
\end{tabular}

3.2. Entities oriented towards short supply chains show stronger dominance than those oriented towards long supply chains

Dominance assessment shows twice as many patches oriented towards short supply chains (10458 patches) relative to long supply chains (5296). Both kinds of entities have similar median surface areas devoted to beef feeding (4.85 ha for SSC vs. 4.58 ha for LSC). Average density of beef feeding areas is almost identical for SSC and LSC (Table 3). However, the patches in short supply chains have larger surface areas on average (36 ha for SSC and 28 ha for LSC), which may indicate strong connectivity between the beef feeding areas selling their production in SSC because they are located close to each other. This connectivity may be accentuated by a neighborhood effect, with breeders in short supply chains creating social links and exchanging best practices [44]. Nevertheless, these results should be considered as an overall trend and verified against expert opinion, given that the SSC variable in our study was estimated using census data at the municipal level due to lack of available data at a finer scale.

Table 3. Density of patches in SSC and LSC

\begin{tabular}{ccccc}
\hline \multirow{2}{*}{ Area (ha) } & Density SSC \% & Density LSC \% & Area SSC (Ha) & Area LSC (Ha) \\
& & & & \\
\hline$<50$ & 31.15 & 31.04 & 3.33 & 3.26 \\
\hline$>50$ & 68.71 & 69.48 & 246.25 & 174.43 \\
\hline$>100$ & 73.32 & 74.63 & 410.33 & 278.06 \\
\hline$>300$ & 77.93 & 79.93 & 975.01 & 602.63 \\
\hline$>500$ & 78.86 & 82.67 & 1389.48 & 801.39 \\
\hline
\end{tabular}




\begin{tabular}{lllll}
\hline$>700$ & 77.87 & 80.91 & 1791.04 & 973.05 \\
\hline$>1000$ & 77.71 & 82.67 & 2289.74 & 1208.73 \\
\hline
\end{tabular}

3.3 A higher proportion of beef feeding areas located within nature parks sell their production in short supply chains

The proportion of areas in SSC to those in LSC is greater within the perimeters of nature parks (regional and national) than in the whole of the study area.

Table 4. Proportion of beef feeding areas in SSC and LSC, for areas located within a national or regional nature park and for whole study area

\begin{tabular}{clll}
\hline & $\begin{array}{l}\text { SSC beef } \\
\text { feeding areas }\end{array}$ & $\begin{array}{l}\text { LSC beef } \\
\text { feeding } \\
\text { areas }\end{array}$ & $\begin{array}{l}\text { Ratio SSC/LSC } \\
\text { areas }\end{array}$ \\
\hline $\begin{array}{c}\text { Within a nature park in the study } \\
\text { area }\end{array}$ & 119160 (ha) & 38236 (ha) & 3,11 \\
\hline Total study area & 264953 (ha) & 107058 (ha) & 2,5 \\
\hline
\end{tabular}

3.4. Beef feeding areas selling their production in short supply chains are closer to slaughterhouses than those selling in long supply chains

Pastoral areas operating in short supply chains are on average $24.888 \mathrm{~km}$ from the nearest slaughterhouse, whereas those operating in long supply chains are on average $27.294 \mathrm{~km}$ from the nearest slaughterhouse.

\subsection{Estimation of beef self-sufficiency ratio}

Finally, we estimated the quantity of beef produced in the $100 \mathrm{~km}$-radius foodshed. Extracting from RGA 2010 the number of beef per municipality, we multiplied this by an average load of 1 bovine livestock unit (LSU) per hectare. The LSU is a reference unit for aggregating livestock of different species and ages using specific coefficients initially established on the basis of the nutritional or feed requirements of each type of animal (source Eurostat). To calculate the $\mathrm{kg}$ carcass equivalent, we applied a yield of 0.74 tonnes per hectare [11]. The yearly consumption of bovine meat was estimated by multiplying the number of inhabitants (INSEE 2014) by the kg carcass equivalent of the 2018 bovine meat consumption per capita (http://www.fao.org/faostat/en/\#data/FBS). The beef self-sufficiency ratio is therefore the ratio of estimated beef production to estimated consumption in the $100 \mathrm{~km}$-radius foodshed, calculated by département as follows:

$$
\text { Beef self }- \text { sufficiency ratio }=\frac{\text { beef feeding area } * \text { yield }}{\text { number of inhabitants } * \text { average consumption per capita/year }}
$$

with beef feeding area $=$ number of bovine livestock * (1hectare/livestock unit)

Table 5. Estimation of beef self-sufficiency ratio

\begin{tabular}{|c|c|c|c|c|c|}
\hline Département & Beef area [ha] & $\begin{array}{l}\text { Estimated beef } \\
\text { production }[t]\end{array}$ & population & $\begin{array}{l}\text { Estimated beef } \\
\text { consumption } \\
\text { per capita, by } \\
\text { year }[t]\end{array}$ & $\begin{array}{l}\text { Estimated beef } \\
\text { self- } \\
\text { sufficiency }\end{array}$ \\
\hline $\begin{array}{l}\text { Alpes de } \\
\text { Haute } \\
\text { Provence } \\
\end{array}$ & 714 & 528 & 110466 & 2286 & $23 \%$ \\
\hline Hautes Alpes & 306 & 226 & 18437 & 381 & $59 \%$ \\
\hline
\end{tabular}




\begin{tabular}{llllll}
\hline Ardèche & 6892 & 5100 & 177552 & 3674 & $139 \%$ \\
\hline $\begin{array}{l}\text { Bouche du } \\
\text { Rhone }\end{array}$ & 12161 & 8999 & 1970436 & 40768 & $22 \%$ \\
\hline Drôme & 4385 & 3245 & 209911 & 4343 & $75 \%$ \\
\hline Gard & 4581 & 3390 & 732863 & 15163 & $22 \%$ \\
\hline Hérault & 642 & 475 & 632437 & 13085 & $444 \%$ \\
\hline Lozère & 2733 & 2022 & 7231 & 150 & $1352 \%$ \\
\hline Var & 0 & 0 & 60793 & 1258 & $0 \%$ \\
\hline Vaucluse & 282 & 209 & 554393 & 11470 & $2 \%$ \\
\hline
\end{tabular}

In the municipalities located in départements with a strong beef production tradition (Drôme and Ardèche), production capacity largely exceeds local consumption, and therefore there is a very high ratio of beef self-sufficiency (1351\% and 139\% respectively). Other départements with less of a beef production tradition (ex. Var) are dependent on external beef supply. It should be noted that these results confirm those of previous studies [11].

To summarize, our results on the geographical factors that characterize the beef feeding areas oriented towards short supply chains are the following:

Table 6. Factors that characterize the beef feeding areas oriented towards short supply chains

\begin{tabular}{ll}
\hline IMPACT & FACTOR \\
\hline++ & Rugosity \\
\hline++ & Dominance \\
\hline++ & Location within Nature Park \\
\hline+ & Distance from Slaughterhouse \\
\hline
\end{tabular}

\section{Discussion}

\subsection{Determinants of the spatial signature of beef feeding areas oriented towards short supply chains}

Our results confirm the initial hypotheses that the rugosity of beef feeding areas is informative on the orientation of food production towards short supply chains [41,45]. On the other hand, there are more patches in SSC than in LSC. One explanation may be increasing urban demand for food grown "close to home" interacting with the processes of rural restructuring to foster small-scale farming and its direct food linkages to cities [46]. In addition, the surface areas of the patches in SSC are larger. It would be interesting to analyze the neighborhood effects to better understand how landscape pattern, and in particular fragmentation (in the sense of landscape ecology), impacts the functioning of the landscape (i.e. agricultural activities on farms). Moreover neighborhood effects should take into account social relations between producers and between producers and urban demand, since an important driver of the archipelago structure is the supply chain.

This work is limited by a lack of sources of statistics on short supply chains at a finer scale than the municipality. As a result, we may be overestimating the beef feeding areas in SSC. Indeed, we assigned to SSC all the cattle feeding areas of any municipality that had at least one beef livestock farmer who declared marketing via SSC (RGA 2010). Our research perspectives include working at a finer scale based on quantitative field surveys and expert opinion, coupled with data from the upcoming RGA 2020, which will be available in 2022. Analyzing this database would also enable us to identify the part of the land in the Bouches du Rhone that is used for raising bulls for bullfighting, currently included in the "cattle" section of the RGA in the same way as beef cows. In addition, a field survey would make it 
possible to specify the type of beef cattle breeding (Charolais, Limousine) and to refine production estimates (e.g. yield/carcass).

As for the effect of public policies on the orientation of land use towards SSC, we analyzed the effect of being located within a regional or national nature park. Our results show that there are 3.11 times more areas under SSC than under LSC inside parks (see Table 4). This may be due both to the parks' actions in support of SSC (e.g. supplying public school canteens with local food products, promoting food quality labels, organizing farmers' markets) and to the territorial dynamics of proximity that the parks promote $[4,30]$.

Finally, distance from slaughterhouses seems to be a factor explaining orientation towards SSC. This should be further addressed by research examining the typology of slaughterhouses (small versus large) and the differences in slaughtering costs. In addition, the possible introduction of mobile slaughterhouses currently being discussed by stakeholders (chamber of agriculture, livestock associations) would likely impact orientation towards short supply chains, attracting small farms and isolated cattle farms in particular. An interesting future extension would therefore be to compare our approach with the stakeholders' expertise by means of a participatory process. It should be noted that the effect of distance from consumption points was not analyzed here, since for beef and for the study area, the average distance in short supply chains is $200 \mathrm{~km}$ (expert opinion).

\subsection{What role and leverage for public action?}

What leverage is there for public action to reconnect beef production areas to consumption areas (the city) through short supply chains? The obvious direction is using development initiatives to increase the connectivity of beef feeding areas (e.g. land acquisition to install new breeders) and rugosity (e.g. protection of small pastoral areas on the outskirts of the city). In addition, public action can play a decisive role in fostering short supply chains through nature parks, as we have seen above. Moreover, public procurement (e.g. local food public procurement for school canteens) can promote local food supply chains by encouraging producer groups, developing partnerships with intermediaries (e.g. butchers for custom cutting) and securing outlets under contract for part of the production [44,47].

Furthermore, from a regional food security perspective, even if all the arable land oriented towards the production of food sold in short supply chains (see Table 5) were used for beef production, none of the départements in our study area except Lozère and Ardèche would be self-sufficient. Would it be possible (and desirable) to encourage farmers to redirect certain pastoral areas (e.g. those used for leisure activities involving horses) to beef feeding in order to produce beef to feed the city? In the end, our results show that the spatial arrangement of areas is also an important consideration, to be added to biophysical and agro-climatic conditions such as altitude, hygrometry, and soil characteristics. It would be interesting to explore whether the foodshed approach - based on the concept of sustainable cityregion food systems - could be integrated more intensively into food policies so as to sustainably increase food self-sufficiency at regional level [48].

\section{Conclusion}

This paper presents an attempt to delimit and characterize the foodshed using concepts from landscape ecology (rugosity, connectivity, and patches and the archipelago) for a specific food product (beef). We discriminated between beef feeding areas oriented towards SSC and those oriented towards LSC using available statistical data to confirm or challenge our hypothesis of a particular spatial signature of agricultural areas oriented towards SSC. Our results show that the beef feeding areas in SSC have a particular spatial arrangement: they are small patches very closely situated $(<20 \mathrm{~m})$ and connected to each other, forming large areas with high-rugosity contours. This confirms the hypothesis of a spatial signature of areas in SSC. In other words, the functioning and management of the landscape are 
translated in space into particular spatial structures whose arrangement is identifiable, as our previous work has shown [4-6,19].

These areas composed of small, connected patches contribute more to city food supply than isolated patches, due to their functional connection in short supply chains. These results, although they do not call into question the productive capacity of isolated farms, are relevant in terms of food security at a regional level from a food planning perspective. By revealing the positive impact of nature parks on the existence of short supply chains, we have shown the decisive role that public action can play.

Author Contributions: Conceptualization, M.M., E.S.-S.; validation, E.S.-S, C.N, M.M and J.L.V.-V; formal analysis, J.L.V.-V and E.S.-S; resources, A.P.; writing - original draft preparation, MM, E.S.-S ; writing review and editing, MM, E.S.-S supervision, MM, E.S.-S,C.N. All authors have read and agreed to the published version of the manuscript.

Funding: This work has been carried out as part of the ongoing Project FOODSHIFT2030, funded from the European Union's Horizon 2020 Research and Innovation Programme under the grant agreement number 862716.

Acknowledgments: The authors want to thank the anonymous reviewers for their diligent work and their helpful advice. Our thanks to Avignon University, UMR 7300, Laboratoire ESPACE for providing the resources of the ESPACE Laboratory and Avignon University, as well as to Guillaume Ollivier (INRAE- UR Ecodéveloppement) for his remarks. We are grateful to the Urbansimul team for their contribution on dilation/erosion (Computer code of the Urbansimul 2016 project). 2016. (hal-01604422)). Thanks to Catherine Brinkley (Department of human ecology, University of California, Davis), Noé Guiraud, post-doctoral researcher (Urban School of Lyon), Mathieu Allemand, cattle breeder in Montfrin (Gard), Laure Marcellin, cattle breeder (Sauron farm) in Ancelle (Hautes Alpes), Albert Alameldine, REGAL network project manager, Hugues Fortuna, manager of the Avignon canteen. We thank Marjorie Sweetko for English language editing.

Conflicts of interest: The authors declare no conflict of interest.

\section{References}

1. IPES-Food COVID-19 and the Crisis in Food Systems: Symptoms, Causes, and Potential Solutions; International Panel of Experts on Sustainable Food Systems, 2020; p. 11;.

2. United Nations Organisation (UNO) World Urbanization Prospects: The 2014 Revision.; UNO. Department of Economic and Social Affairs. Population Division, 2014; p. 517;

3. Moragues-Faus, A. Distributive Food Systems to Build Just and Liveable Futures. Agric Hum Values 2020, doi:10.1007/s10460-020-10087-9.

4. Sanz Sanz, E. Planification Urbaine et Agriculture. Méthodologie Systémique de Caractérisation de l'agriculture Périurbaine à Partir d'une Recherche Empirique En France et En Espagne. Thèse pour l'obtention du titre de docteur en géographie (UAM) et en études urbaines (EHESS), EHESS/UAM, 2016.

5. Sanz Sanz, E.; Martinetti, D.; Napoléone, C. Operational Modelling of Peri-Urban Farmland for Public Action in Mediterranean Context. Land Use Policy 2018, 75, 757-771, doi:10.1016/j.landusepol.2018.04.003.

6. Boussougou Boussougou, G.; Sanz Sanz, E.; Napoléone, C.; Martinetti, D. Identifying Agricultural Areas with Potential for City Connections: A Regional-Scale Methodology for Urban Planning. Land Use Policy 2021, 103, 105321, doi:10.1016/j.landusepol.2021.105321.

7. Vicente-Vicente, J.L.; Sanz-Sanz, E.; Napoléone, C.; Moulery, M.; Piorr, A. Foodshed, Agricultural Diversification and Self-Sufficiency Assessment: Beyond the Isotropic Circle Foodshed-A Case Study from Avignon (France). Agriculture 2021, 11, 143, doi:https://doi.org/10.3390/agriculture11020143.

8. Hedden, W.P. How Great Cities Are Fed; D . C . Heath\&Cp.; Boston, Mass., 1929; 
9. Kloppenburg, J.; Hendrickson, J.; Stevenson, G.W. Coming in to the Foodshed. Agriculture and Human Values 1996, 13,33-42, doi:10.1007/BF01538225.

10. Butler, M. Analyzing the Foodshed: Toward a More Comprehensive Foodshed Analysis; 2000;

11. Feagan, R. The Place of Food: Mapping out the "local" in Local Food Systems. Progress in Human Geography 2007, 31, 23-42, doi:10.1177/0309132507073527.

12. Peters, C.J.; Bills, N.L.; Wilkins, J.L.; Fick, G.W. Foodshed Analysis and Its Relevance to Sustainability. Renew. Agric. Food Syst. 2009, 24, 1-7, doi:10.1017/S1742170508002433.

13. Aubry, C.; Kebir, L. Shortening Food Supply Chains: A Means for Maintaining Agriculture Close to Urban Areas? The Case of the French Metropolitan Area of Paris. Food Policy 2013, 41, 85-93, doi:10.1016/j.foodpol.2013.04.006.

14. Griffin, T.; Conrad, Z.; Peters, C.; Ridberg, R.; Tyler, E.P. Regional Self-Reliance of the Northeast Food System. Renew. Agric. Food Syst. 2015, 30, 349-363, doi:10.1017/S1742170514000027.

15. Tichenor, N.E.; van Zanten, H.H.E.; de Boer, I.J.M.; Peters, C.J.; McCarthy, A.C.; Griffin, T.S. Land Use Efficiency of Beef Systems in the Northeastern USA from a Food Supply Perspective. Agricultural Systems 2017, 156, 34-42, doi:10.1016/j.agsy.2017.05.011.

16. Li, K.; Jin, X.; Ma, D.; Jiang, P. Evaluation of Resource and Environmental Carrying Capacity of China's RapidUrbanization Areas-A Case Study of Xinbei District, Changzhou. Land 2019, 8, 69, doi:10.3390/land8040069.

17. Zasada, I.; Schmutz, U.; Wascher, D.; Kneafsey, M.; Corsi, S.; Mazzocchi, C.; Monaco, F.; Boyce, P.; Doernberg, A.; Sali, G.; et al. Food beyond the City - Analysing Foodsheds and Self-Sufficiency for Different Food System Scenarios in European Metropolitan Regions. City, Culture and Society 2019, 16, 25-35.

18. Kindlmann, P.; Burel, F. Connectivity Measures: A Review. Landscape Ecol 2008, s10980-008-9245-4, doi:10.1007/s10980-008-9245-4.

19. Poggi, S.; Vinatier, F.; Hannachi, M.; Sanz Sanz, E.; Rudi, G.; Zamberletti, P.; Tixier, P.; Papaïx, J. How Can Models Foster the Transition towards Future Agricultural Landscapes? Advances in Ecological Research 2021, S0065250420300453, doi:10.1016/bs.aecr.2020.11.004.

20. Lomolino, MarK.V. A Call for a New Paradigm of Island Biogeography: Island Paradigms. Global Ecology and Biogeography 2000, 9, 1-6, doi:10.1046/j.1365-2699.2000.00185.x.

21. MacArthur, R.H.; Wilson, E.O. The Theory of Island Biogeography; Princeton University Press: Princeton, 1967;

22. Vogiatzakis, I.; Griffiths, G.H. Island Biogeography and Landscape Ecology. In Mediterranean Island Landscapes; Vogiatzakis, I., Pungetti, G., Mannion, A.M., Eds.; Landscape Series; Springer: Dordrecht, 2008; Vol. 9, p. 41.

23. Bueno, A.S.; Peres, C.A. Patch-scale Biodiversity Retention in Fragmented Landscapes: Reconciling the Habitat Amount Hypothesis with the Island Biogeography Theory. J Biogeogr 2019, 46, 621-632, doi:10.1111/jbi.13499.

24. Liira, J.; Jürjendal, I.; Paal, J. Do Forest Plants Conform to the Theory of Island Biogeography: The Case Study of Bog Islands. Biodivers Conserv 2014, 23, 1019-1039, doi:10.1007/s10531-014-0650-5.

25. Pulliam, H.R. Sources, Sinks, and Population Regulation. The American Naturalist 1988, 132, 652-661, doi: $10.1086 / 284880$.

26. Décamps, H.; Décamps, O. Organisation de l'espace et processus écologiques. economierurale 2007, 41-54, doi:10.4000/economierurale.1990.

27. Taylor, P.D.; Fahrig, L.; Henein, K.; Merriam, G. Connectivity Is a Vital Element of Landscape Structure. Oikos 1993, 68, 571, doi:10.2307/3544927.

28. Taylor, P.D.; Fahrig, L.; With, K.A. Landscape Connectivity: A Return to the Basics. In Connectivity Conservation; Crooks, K.R., Sanjayan, M., Eds.; Cambridge University Press: Cambridge, 2006; pp. 29-43 ISBN 978-0-511-754821.

29. Torre, A.; Wallet, F. Introduction: The Role of Proximity Relations in Regional and Territorial Development Processes. In Regional Development and Proximity Relations; Edward Elgar Publishing, 2014; pp. 1-44 ISBN 978-178100-289-6.

30. Angeon, V.; Bertrand, N. Les Dispositifs Français de Développement Rural : Quelles Proximités Mobilisées ? Géographie, économie, société 2009, 11, 93-114, doi:10.3166/ges.11.93-114.

31. Hinrichs, C.C. Embeddedness and Local Food Systems: Notes on Two Types of Direct Agricultural Market. Journal of rural studies 2000, 16, 295-303.

32. Brinkley, C. Visualizing the Social and Geographical Embeddedness of Local Food Systems. Journal of Rural Studies 2017, 54, 314-325, doi:10.1016/j.jrurstud.2017.06.023.

33. Chiffoleau, Y. From Politics to Co-Operation: The Dynamics of Embeddedness in Alternative Food Supply Chains. Sociologia Ruralis 2009, 49, 218-235, doi:10.1111/j.1467-9523.2009.00491.x.

34. Guiraud, N.; Laperrière, V.; Rouchier, J. Une Géographie Des Circuits Courts En Région Provence-Alpes-Côte d'azur. L'Espace géographique 2014, 4, 356-373.

35. Girardet, X.; Foltête, J.-C.; Clauzel, C.; Vuidel, G. Restauration de la connectivité écologique : proposition méthodologique pour une localisation optimisée des passages à faune. vertigo 2016, doi:10.4000/vertigo.17337.

36. Guérois, M. Les Formes Des Villes Européennes Vues Du Ciel. Une Contribution de l'image CORINE Land Cover à La Comparaison Morphologique Des Grandes Villes d'Europe Occidentale., Université Panthéon-Sorbonne-Paris I, 2003.

37. Amsallem, J.; Deshayes, M.; Bonnevialle, M. Analyse comparative de méthodes d'élaboration de trames vertes et bleues nationales et régionales. Sciences Eaux \& Territoires 2010, Numéro 3, 40, doi:10.3917/set.003.0040.

38. Geniaux, G.; Leroux, B.; Samaké, A.D.; Cezanne-Bert, P.; Moulery, M. Code Informatique Du Projet Urbansimul 2016; 2016;

39. du Gerny, S. Les Abattoirs de Proximité de plus En plus Sollicités Par Les Petits Producteurs. Les Echos 2015.

40. Dustan, P.; Doherty, O.; Pardede, S. Digital Reef Rugosity Estimates Coral Reef Habitat Complexity. PLoS ONE 2013, 8, e57386, doi:10.1371/journal.pone.0057386. 
41. Brinkley, C. High Rugosity Cities: The Geographic, Economic and Regulatory Pathology of America's Most NonConcentric Urban Areas. Land Use Policy 2018, 73, 215-224, doi:10.1016/j.landusepol.2018.01.024.

42. Barké, M.K.; Oussein, I.; Bielders, C.; Ambouta, K.J.M.; Tychon, B. Caractérisation morphologique des cuvettes oasiennes du Centre-Est du Niger. physio-geo 2017, 255-276, doi:10.4000/physio-geo.5607.

43. Angeon, V.; Boisvert, V.; Caron, A. La marque « Parc naturel régional »: Un outil au service d'un développement local durable et un modèle pour les pays du Sud? Afrique contemporaine 2007, 222, 149, doi:10.3917/afco.222.0149.

44. Agence Nationale de la Cohesion des Territoires; Massif des Alpes Compte Rendu Du Séminaire "Valoriser Les Viades de Montagne Massif Des Alpes"; Chanmbre d'Argiruclure à Grenoble, 2020;

45. Forman, R.T.T. Urban Regions: Ecology and Planning beyond the City; Harvard University: Massachusetts, 2008; ISBN 10.1017/CBO9780511754982.

46. Jarosz, L. The City in the Country: Growing Alternative Food Networks in Metropolitan Areas. Journal of Rural Studies 2008, 24, 231-244, doi:10.1016/j.jrurstud.2007.10.002.

47. Sanz Sanz, E. Public Procurement as a Booster of Midscale Food Supply Chains. In Public food procurement for sustainable food systems and healthy diets; Swenson, L., Hunter, D., Schneider, S., Eds.; 2022.

48. Gugerell, C.; Sato, T.; Hvitsand, C.; Toriyama, D.; Suzuki, N.; Penker, M. Know the Farmer That Feeds You: A Cross-Country Analysis of Spatial-Relational Proximities and the Attractiveness of Community Supported Agriculture. Agriculture 2021, 11, 1006, doi:10.3390/agriculture11101006. 